Article

\title{
Food Waste Auditing at Three Florida Schools
}

\author{
Ann C. Wilkie *, Ryan E. Graunke and Camilo Cornejo \\ Soil and Water Science Department, University of Florida-IFAS, P.O. Box 110960, Gainesville, \\ FL 32611-0960, USA; E-Mails: reg1214@ufl.edu (R.E.G.); ccordav1@ufl.edu (C.C.) \\ * Author to whom correspondence should be addressed; E-Mail: acwilkie@ufl.edu; \\ Tel.: +1-352-392-8699; Fax: +1-352-392-7008.
}

Academic Editor: Kirrilly Thompson

Received: 17 November 2014 / Accepted: 12 January 2015 / Published: 27 January 2015

\begin{abstract}
School cafeterias are a significant source of food waste and represent an ideal opportunity for diverting food waste from landfills. In this study, cafeteria waste audits were conducted at three Florida schools. Food waste comprised the largest fraction of school cafeteria waste streams, ranging from $47 \%$ to $58 \%$, followed by milk, paper products (tissue, milk cartons, pasteboard, paper plates, and cardboard), and plastics (plastic wrap, packaging, and utensils). Metal and glass comprised the smallest fraction of the waste stream. Average total waste generation ranged from 50.5 to $137.6 \mathrm{~g} \cdot \mathrm{student}^{-1} \cdot \mathrm{day}^{-1}$. The mean generation rates for food waste ranged from 24.7 to $64.9 \mathrm{~g} \cdot$ student $^{-1}$. day $^{-1}$. The overall average for cafeteria waste generation among all three schools was $102.3 \mathrm{~g} \cdot$ student $^{-1} \cdot$ day $^{-1}$, with food waste alone contributing $52.2 \mathrm{~g} \cdot$ student $^{-1} \cdot$ day $^{-1}$. There are two primary approaches to diverting school food waste from landfills: reduction and recycling. Food waste can be reduced through educating students and staff in order to change behaviors that cause food waste. Food waste can be collected and recycled through composting or anaerobic digestion in order to generate beneficial end products, including soil amendments and bioenergy. Over $75 \%$ of the cafeteria waste measured in this study could be recycled in this manner.
\end{abstract}

Keywords: cafeteria waste; school food waste; waste audit; recycling; waste generation rates; landfill diversion; anaerobic digestion; composting; bioenergy; sustainability 


\section{Introduction}

Food waste and its consequent environmental, societal, and economic impacts are attracting increasing attention across the globe [1]. The Food and Agriculture Organization of the United Nations (FAO) estimates that approximately one-third of global food production is lost or wasted [2]. Global efforts, such as the Food Loss and Waste Protocol, are currently underway to help identify, quantify, and reduce food waste [3]. In developed countries, large quantities of preventable food waste are generated further down the food production chain at the post-retail, consumption level. While food waste from households represents a significant source of consumption-level food waste [4], the institutional food service sector (schools, prisons, hospitals) is also a major source of food waste in developed countries [5]. Schools in particular are ubiquitous in our communities and play an important role in all of our lives. Schools typically serve meals at a single location (i.e., cafeteria) to a large number of individuals and the resulting food waste is collected at a single point. By comparison, an equal number of meals served at households would span a large area of a municipality, making collection more difficult. The concentrated food waste stream from school cafeterias presents an ideal opportunity for diverting food waste from landfills by reducing and/or recycling this food waste. The first step in assessing the potential of efforts to divert food waste from schools is to quantify the amount of food waste generated at the individual school level. The aim of this study was to measure the total cafeteria waste and specifically the food waste from three local schools by conducting waste audits on the waste stream generated from their school cafeterias.

Uneaten food from school-provided lunches is a major source of cafeteria food waste. Numerous studies have been conducted to directly or indirectly measure the amount of food discarded from school-provided lunches in order to assess students' nutritional intake [6-8]. These studies considered many different factors and measured the amount of waste from each constituent of the lunch provided. Typical values ranged from $20 \%$ to $50 \%$ of the items served being wasted, with vegetables and fruit in the higher range and entrée (meat and grain) in the lower range. In the United States, the National School Lunch Program (NSLP) sponsored by the United States Department of Agriculture (USDA) provides subsidies to schools that serve lunches in accordance with the NSLP nutrition requirements, with lunches provided to 31 million students in 2012 [9]. The Healthy, Hunger-Free Kids Act of 2010, which took effect in the 2012-2013 school year, was a major revision to the nutrition requirements of the NSLP and made several changes to school-provided meals. One of the most significant changes, as it pertains to food waste, is that all students are now required "to be served" a fruit or vegetable with lunch [10]. Prior to these changes, schools were required "to offer" fruit or vegetable, but not required to serve the fruit or vegetable to every student. There is concern among the public, school administrators, and elected officials that this change is causing an increase in food waste, particularly fruit and vegetable waste, and additional costs to schools for serving fruits or vegetables to students who will not eat them [11]. Studies comparing food waste before and after the implementation of this rule show mixed results. Just and Price [12] found that requiring students to take at least one serving of fruit or vegetable at three elementary schools (kindergarten through 5th grade) in Utah significantly increased the amount of fruits and vegetables wasted, from 0.17 to 0.92 servings discarded per student. Cohen et al. [13], however, found that after implementation of the new rules at three primary schools (3rd through 8th grade) in a low-income, urban school district in Massachusetts, the percent of vegetables wasted actually decreased 
from $74.2 \%$ to $59.7 \%$, but fruit wasted increased slightly from $40.9 \%$ to $43.1 \%$. Byker et al. [14] measured food waste generated from pre-school and kindergarten students receiving NSLP lunches after implementation of the new regulations at an elementary school in an urban cluster of a rural county in the southwestern United States. Over the course of a week, overall food wastage was $45.3 \%$, with vegetables discarded in the highest amount (51.4\%) and fruit in the lowest amount (33.0\%). However, there was significant variability in the amount of food wasted during the week; vegetables ranged from $26.1 \%$ to $80 \%$, depending on the day. These studies show the effect of students' preferences and behavior, and the effect of food service regime, on food waste from school-provided lunches, especially in light of the new NSLP requirements. However, these studies are not complete food waste audits and do not account for food waste from lunches that students bring from home, waste from kitchen preparation, or waste from schools not participating in the NSLP program.

School cafeteria waste audits measuring the amount of cafeteria waste and total food waste generated from school kitchens and dining areas are less well documented in the United States than plate waste studies, and the few studies reported give widely varying generation rates. Based on literature reviews, the Connecticut Department of Energy and Environmental Protection (CDEEP) [15] used a value of $159 \mathrm{~g} \cdot$ student $^{-1} \cdot$ day $^{-1}$ to estimate school food waste for their spatial analysis of food waste generation in the state. In a study of food waste generation in a single county in upstate New York (Tompkins County), Griffin et al. [16] estimated the rate of discarded food waste at schools to be $227 \mathrm{~g} \cdot$ student $^{-1} \cdot$ day $^{-1}$ based on their review of the literature. Hollingsworth et al. [17] measured total cafeteria waste generation rates in four middle schools and two elementary schools in Baton Rouge Parish, Louisiana for a 5-day period and found an average food waste generation rate of $130 \mathrm{~g} \cdot$ student $^{-1} \cdot$ day $^{-1}$. Hollingsworth et al. [18] also measured total cafeteria waste generation rates at seven schools (2 elementary, 2 middle and 3 primary; kindergarten through 8th grade) in Ascension Parish, Louisiana for a 10-day period and found an average food waste generation rate of $171 \mathrm{~g} \cdot$ student $^{-1} \cdot$ day $^{-1}$. Johnson et al. [19] used an estimate for school food waste production of $0.7 \mathrm{~kg} \cdot$ employee $^{-1} \cdot$ day $^{-1}$ at public schools in Florida which translates to $83.3 \mathrm{~g} \cdot \mathrm{student}^{-1} \cdot \mathrm{day}^{-1}$ based on the current Florida public school full-time staff $(320,349)$ to public school student $(2,691,322)$ ratio [20,21]. In Minnesota over a 2-day period, the Minnesota Pollution Control Agency (MPCA) [22] audited both urban and suburban total school waste at two elementary schools, two middle schools, and two high schools and determined that the average food waste production at public schools was $56.4 \mathrm{~g} \cdot$ student $^{-1} \cdot$ day $^{-1}$. A waste audit conducted at a dining hall at the University of Florida found a food waste generation rate of $158.8 \mathrm{~g} \cdot$ student $^{-1} \cdot \mathrm{day}^{-1}$ [23]. These few studies show that there are scant data with a wide range of waste generation rates, and demonstrate the need for more current waste audits that thoroughly measure the amount of waste generated by school cafeterias.

Focusing on food waste at schools represents an ideal opportunity for addressing institutional food waste for several reasons. First, the fact that public schools fall under the jurisdiction of the local school board could allow unified educational campaigns to reduce food waste and coordinated food waste recycling programs that could improve the cost effectiveness of such programs. Also, cafeterias are a more controlled environment than other food service areas due to a regular, daily attendance by the same students eating in the same cafeteria, often for several years. Further, educational campaigns, which could be incorporated into existing science and engineering curricula, to minimize food waste, to divert this food waste from landfills, and to transform these materials into energy and soil amendments through 
composting or anaerobic digestion, offer unique educational opportunities in resource conservation, environmental stewardship, and sustainability that are critical for our future citizens, especially for developing leaders among them. These educational campaigns could have even greater impacts for fostering sustainability as these students, upon becoming aware of food waste and learning techniques to reduce or recycle food waste, bring these lessons home and influence their parents to also reduce their household food waste [24].

The objectives of this study were to determine the amount of total cafeteria waste and food waste generated at three schools in Gainesville, Florida and to compare the composition of cafeteria waste at these schools. Such data are an essential first step towards future research to assess the potential for reducing and recycling food waste at schools. Before any comprehensive food waste reduction or recycling regime can be implemented, it must first be known how much food waste is generated.

\section{Materials and Methods}

Three schools located in Alachua County, Florida in the vicinity of Gainesville, were chosen for sequential cafeteria waste audits: a public elementary school, a technical alternative high school, and a private combined middle and high school (Table 1). These three schools represent a cross-section of schools in the local area and were selected in an effort to compare cafeteria waste generation at different types of schools with different food service regimes. The audits were conducted over consecutive two-week periods of the school year, prior to implementation of the Healthy, Hunger-Free Kids Act in the 2012-2013 school year.

Table 1. Characteristics of three Florida schools selected for a cafeteria waste audit.

\begin{tabular}{|c|c|c|c|}
\hline Characteristic & School A & School B & School C \\
\hline Type & Public Elementary & Public Technical High & Private Middle/High \\
\hline Grades & kindergarten -5 th & 9th-12th & 6th-12th \\
\hline Student enrollment ${ }^{a}$ & 436 & 247 & 355 \\
\hline $\begin{array}{l}\text { Free or reduced-cost } \\
\text { meals eligibility }{ }^{a}\end{array}$ & $52.56 \%$ & $59.22 \%$ & N/A \\
\hline Auditing days & 8 & 7 & 5 \\
\hline Meal source & $\begin{array}{l}\text { School kitchen or } \\
\text { brought from home }\end{array}$ & $\begin{array}{l}\text { School kitchen or } \\
\text { brought from home }\end{array}$ & $\begin{array}{l}\text { Catered boxed lunches } \\
\text { or brought from home }\end{array}$ \\
\hline Breakfast served & Yes & Yes & No \\
\hline $\begin{array}{l}\text { Number of breakfast } \\
\text { meals served per day a,b }\end{array}$ & 98 & 67 & N/A \\
\hline Lunch served & Yes & Yes & Yes \\
\hline $\begin{array}{l}\text { Number of lunch meals } \\
\text { served per day }{ }^{a, b}\end{array}$ & 282 & 89 & 130 \\
\hline $\begin{array}{l}\text { All students eat in } \\
\text { cafeteria }\end{array}$ & Yes & Yes & Yes \\
\hline Kitchen waste ${ }^{c}$ & No & Yes & No \\
\hline Recycling bins & No & No & Yes \\
\hline Vending machines & No & Yes & Yes \\
\hline
\end{tabular}




\subsection{School A (Public Elementary School)}

School A is a suburban public elementary school (kindergarten-5th grade) located in Gainesville, Florida. During the school year of this audit, the school had 436 enrolled students. All waste generated from the dining area during the breakfast and lunch periods was collected and sorted. This included all post-consumer waste from students who purchased or received a school-provided meal and all waste from students who brought food from home. At School A, the kitchen food waste was minimal, as reported by the cafeteria staff, because the kitchen received most food items pre-prepared or pre-packaged. Therefore, kitchen wastes were not collected in the waste audit. Cafeteria waste was collected on eight consecutive school days.

\subsection{School B (Public Technical High School)}

School B is a suburban public, career and technical alternative high school (9-12th grade) located in Gainesville, Florida and had 247 students enrolled during the school year of the audit. A career and technical high school is one in which the curricula focus more on specific career preparation rather than general education. Food was prepared in the kitchen at School B more than at School A and generated large amounts of food waste. Therefore, School B kitchen waste was included in the audits. Kitchen waste included all waste from trash cans in the food preparation area. Dining room waste included all post-consumer waste from school-provided food as well as waste from food brought from home. Kitchen waste was sorted separately from dining waste. However, for simplicity of presenting the data, kitchen and dining wastes are combined. Vending machines that provided drinks and snack foods were present in the dining area. At School B, kitchen and dining wastes from breakfast and lunch were collected on seven school days.

\subsection{School C (Private Middle and High School)}

School $\mathrm{C}$ is a suburban private school combining elementary (kindergarten-5th grade), middle (6-8th grade) and high (9-12th grade) schools located in Gainesville, Florida. The combined dining area for the middle and high school grades is separate from that of the elementary grades. The waste audit was conducted in the cafeteria for the middle and high schools, in which 355 students were enrolled in the school year of the audit. School C, unlike the other two schools, does not have a kitchen and all food is either catered (e.g., pizza or boxed lunches) to the lunch room from off-campus vendors or brought from home by the students themselves. Breakfast was not offered at School C. Vending machines that provided drinks and snack foods were present in the dining area, and separate recycling bins for bottles and cans were in place next to waste bins in the dining area. The recyclables in these bins were not included in the audit as the goal of the study was to examine waste currently disposed of in landfills. Cafeteria waste was collected on five consecutive school days.

\subsection{Waste Audit Methodology}

At all three schools, dining area waste is normally deposited into waste bins by the students. At School $\mathrm{B}$, kitchen waste was deposited in waste bins by staff. Bins are then emptied into dumpsters for landfill disposal. Given the inherent issues with sampling heterogeneous materials, such as solid waste [25], the 
entire daily waste stream from the schools' food service areas was collected and sorted for the duration of the audits. School staff cooperated in the audits through carefully setting aside the waste collected from the dining and/or kitchen areas in separate garbage bags and providing access to pick up the bagged waste from the schools for transport to the Bioenergy and Sustainable Technology Laboratory at the University of Florida. The totality of the waste was sorted by hand into tared 18-L plastic buckets and weighed on an Ohaus D-5 digital scale (Ohaus Corporation, Parsippany, NJ, USA). Sorting was performed immediately after daily pick-up to reduce evaporation. The entire contents of each bag was sorted in impermeable trays to prevent run-off and allow collection of free-standing liquids. Any opened or unopened drink containers and any residual liquids in the sorting tray were poured into a tared container and weighed. These liquids consisted overwhelmingly of milk, as was evidenced by the minimal amount of plastic bottles and aluminum cans in the waste, but also included some soda, juice, or water. Other than food and milk, the waste was further sorted into different components including: cardboard, milk cartons, office paper, pasteboard, paper plates, tissue paper, plastic bags, plastic bottles, plastic containers, plastic packaging, plastic wrap, Styrofoam, straws, utensils, plastic zipper bags, aluminum cans, aluminum foil, and glass. These components are described in Table 2.

Table 2. Description of waste components measured in cafeteria waste audits.

\begin{tabular}{|c|c|c|}
\hline Component & Description & Waste type \\
\hline Food & $\begin{array}{l}\text { Plate waste from school-provided meals and meals brought from home, food } \\
\text { preparation waste (School B only), includes lunch and breakfast (if applicable) }\end{array}$ & Food \\
\hline Milk & $\begin{array}{l}\text { Milk in opened or unopened cartons, includes any residual liquids in the waste } \\
\text { (minimal compared to volume of milk) }\end{array}$ & Milk \\
\hline Cardboard & $\begin{array}{l}\text { Corrugated cardboard, such as pizza boxes or boxes collected in the kitchen } \\
\text { waste (School B only) }\end{array}$ & Paper \\
\hline Milk cartons & Empty milk cartons (paper material with a wax or plastic coating) & Paper \\
\hline Office paper & Sheets or scraps of white or colored office paper & Paper \\
\hline Pasteboard & Un-corrugated cardboard & Paper \\
\hline Paper plates & Standard paper plates & Paper \\
\hline Tissue paper & Napkins, paper towels, deli paper, paper bags & Paper \\
\hline Plastic bags & Standard plastic shopping bags & Plastic \\
\hline Plastic bottles & Plastic water, juice, or soda bottles & Plastic \\
\hline Plastic containers & Plastic cups, clamshell containers, and similar items & Plastic \\
\hline Plastic packaging & Plastic chip bags, wrappers, and similar items & Plastic \\
\hline Plastic wrap & $\begin{array}{l}\text { Clear plastic sheet wrap, such as cellophane or Saran wrap, clear plastic bags for } \\
\text { utensils, etc. }\end{array}$ & Plastic \\
\hline Styrofoam & Expanded polystyrene cups, plates, or serving trays & Plastic \\
\hline Straws & Disposable plastic straws & Plastic \\
\hline Utensils & Disposable plastic utensils & Plastic \\
\hline Zipper bags & Re-sealable plastic storage bags & Plastic \\
\hline Al cans & Aluminum soda or juice cans & Al \& Glass \\
\hline Al foil & Aluminum foil sheets or aluminum trays from the kitchen & Al \& Glass \\
\hline Glass & Glass soda or juice bottles & Al \& Glass \\
\hline
\end{tabular}




\subsection{Data Analysis}

The various components of the waste stream were grouped into five main fractions based on waste type: food, milk, paper (cardboard, milk cartons, office paper, pasteboard, paper plates, and tissue paper), plastic (bags, bottles, containers, packaging, wrap, Styrofoam, straws, and utensils), and aluminum (cans and foil) and glass (Table 2). The mean percentage contribution of each waste fraction to the total waste collected at each school was determined using the mean daily generation rate of each fraction as a percent of the mean daily total waste generation rate. Daily attendance data from the schools were used to calculate the mean and standard deviation of the generation rate on a per student basis for waste components at the three schools based on the mean daily per student generation of each component at each school. Finally, the mean per student generation rates for food service waste and fractions were compared to levels found in the literature.

\section{Results}

The daily total waste and waste fractions from the cafeteria waste audit at each school are shown in Figures 1-3. School A showed the greatest variability in total daily waste (Figure 1). This may be due to the nature of the younger elementary school students who may be more selective about what they eat from a certain day's menu. The mean daily component weights and student attendance data from the cafeteria waste audit at each school are shown in Table 3. For all three schools, food waste was the predominant component found in the collected waste. The mean percentage contribution of each cafeteria waste fraction to the daily total waste generation rate at each school is depicted in Figure 4.

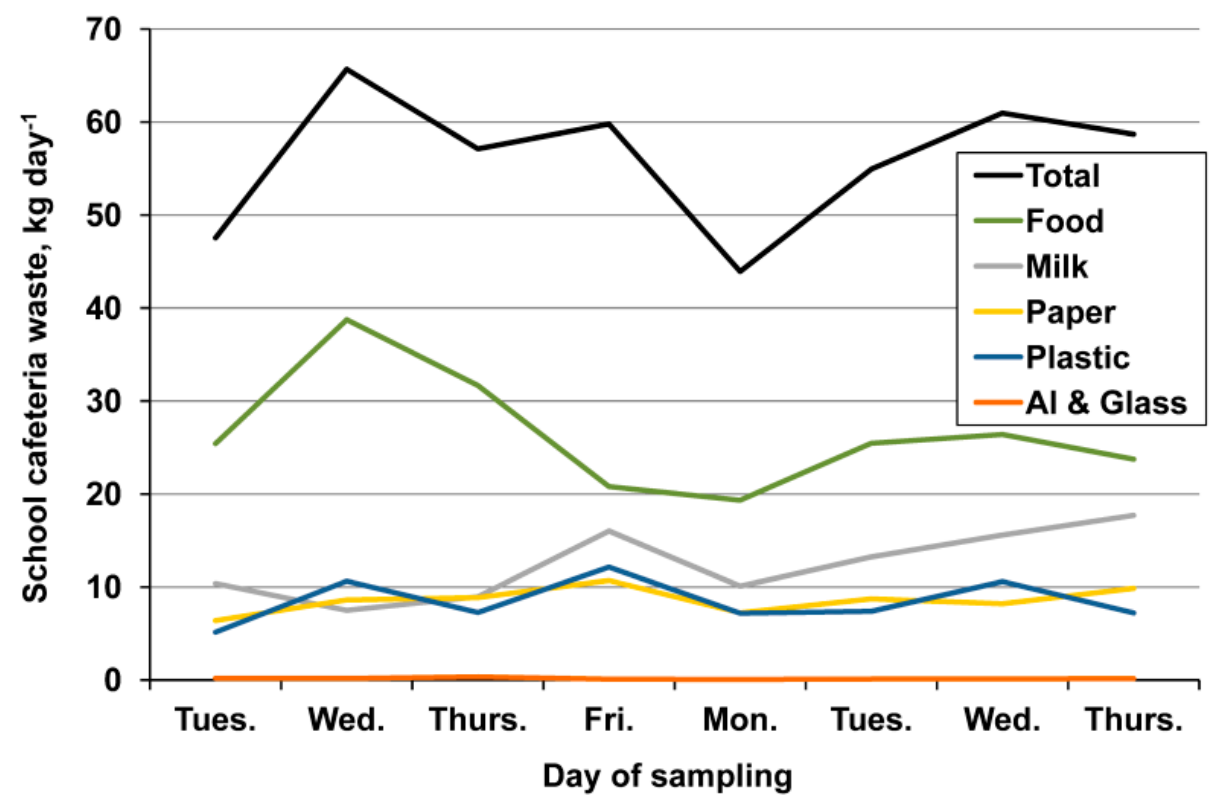

Figure 1. Total waste and waste fraction weights from a cafeteria waste audit at School A, a public elementary school in Alachua County, Florida. 


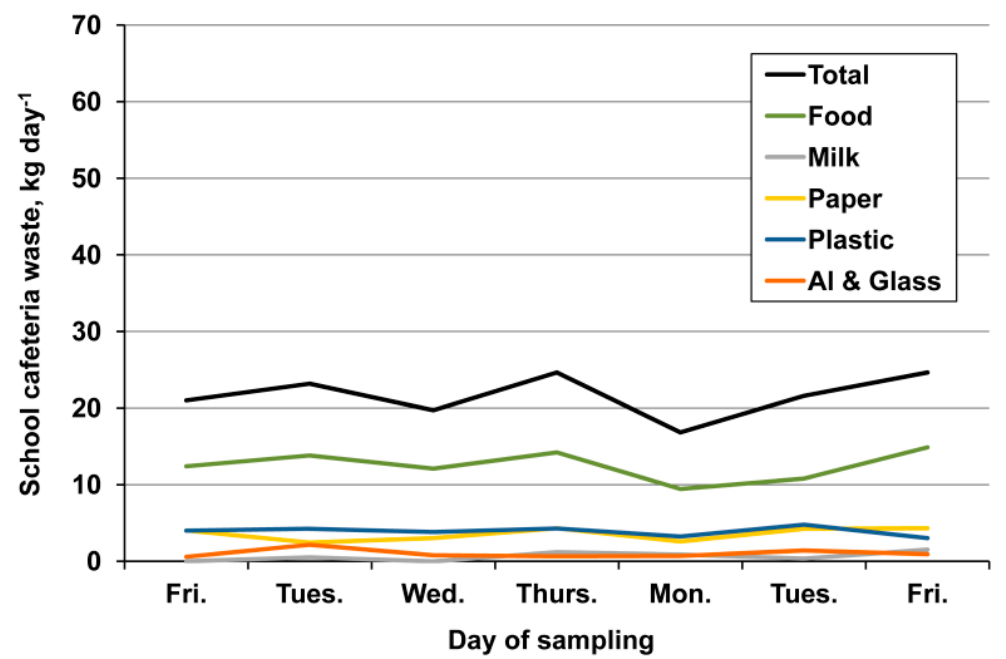

Figure 2. Total waste and waste fraction weights from a cafeteria waste audit at School B, a public technical high school in Alachua County, Florida.

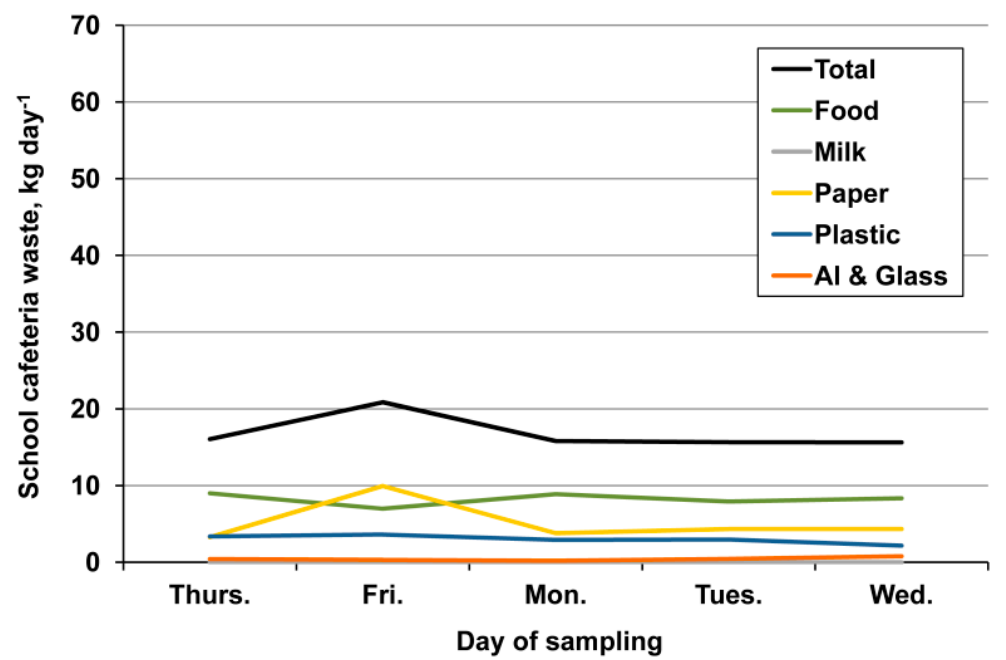

Figure 3. Total waste and waste fraction weights from a cafeteria waste audit at School C, a private middle and high school in Alachua County, Florida.
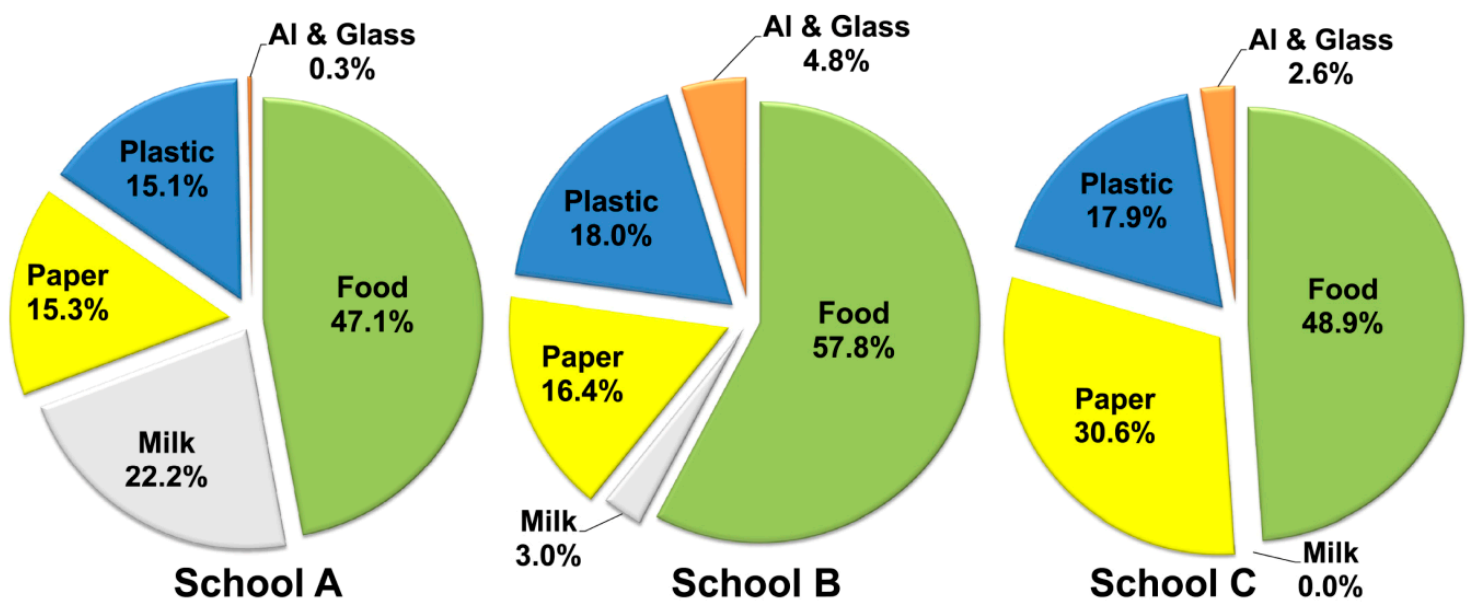

Figure 4. Mean percentage of waste fractions from cafeteria waste audits at three Florida schools. 
Table 3. Mean daily component weights and attendance from cafeteria waste audits at three Florida schools.

\begin{tabular}{lcccccc}
\hline \multicolumn{1}{c}{ Component } & \multicolumn{2}{c}{ School A $(\boldsymbol{n}=\mathbf{8})$} & \multicolumn{2}{c}{ School B $(\boldsymbol{n}=\mathbf{7})$} & \multicolumn{2}{c}{ School C $(\boldsymbol{n}=\mathbf{5})$} \\
\hline \multicolumn{1}{c}{ kg $\cdot$ day $^{-1}$} & Mean & Std. dev. & Mean & Std. dev. & Mean & Std. dev. \\
\hline Food & 26.46 & 6.22 & 12.52 & 1.95 & 8.23 & 0.82 \\
\hline Milk & 12.44 & 3.73 & 0.64 & 0.58 & 0.00 & 0.00 \\
\hline Cardboard & 0.03 & 0.08 & 0.58 & 0.63 & 1.67 & 3.62 \\
Milk cartons & 4.48 & 0.40 & 0.57 & 0.26 & 0.00 & 0.00 \\
Office paper & 0.00 & 0.00 & 0.00 & 0.00 & 0.24 & 0.19 \\
Pasteboard & 1.07 & 0.68 & 0.98 & 0.94 & 1.67 & 1.13 \\
Paper plates & 0.00 & 0.00 & 0.00 & 0.00 & 0.29 & 0.65 \\
Tissue paper & 3.00 & 0.91 & 1.42 & 0.26 & 1.27 & 0.23 \\
$\quad$ Total Paper & 8.58 & 1.36 & 3.55 & 0.84 & 5.14 & 2.72 \\
\hline Plastic bags & 0.03 & 0.04 & 0.04 & 0.05 & 0.20 & 0.04 \\
Plastic bottles & 0.17 & 0.22 & 0.38 & 0.28 & 0.46 & 0.36 \\
Plastic containers & 1.83 & 0.79 & 0.75 & 0.49 & 0.94 & 0.38 \\
Plastic packaging & 2.64 & 1.32 & 1.15 & 0.45 & 0.34 & 0.07 \\
Plastic wrap & 0.33 & 0.28 & 0.63 & 0.60 & 0.20 & 0.12 \\
Styrofoam & 1.27 & 1.70 & 0.67 & 0.26 & 0.34 & 0.31 \\
Straws & 0.20 & 0.09 & 0.03 & 0.03 & 0.00 & 0.00 \\
Utensils & 0.87 & 0.08 & 0.19 & 0.05 & 0.31 & 0.16 \\
Zipper bags & 1.11 & 0.53 & 0.06 & 0.05 & 0.22 & 0.05 \\
$\quad$ Total Plastic & 8.45 & 2.38 & 3.90 & 0.62 & 3.01 & 0.55 \\
\hline Al cans & 0.04 & 0.05 & 0.99 & 0.50 & 0.20 & 0.05 \\
Al foil & 0.13 & 0.05 & 0.04 & 0.08 & 0.21 & 0.21 \\
Glass & 0.00 & 0.00 & 0.00 & 0.00 & 0.03 & 0.07 \\
$\quad$ Total Al \& Glass & 0.17 & 0.09 & 1.03 & 0.56 & 0.44 & 0.22 \\
\hline Total Waste & 56.10 & 7.17 & 21.64 & 2.82 & 16.82 & 2.27 \\
Attendance & 407 & 3.89 & 219 & 9.89 & 333 & 3.24 \\
\hline
\end{tabular}

$n=$ days of sampling

The mean and standard deviation of the daily generation rates of cafeteria waste fractions on a per student basis, based on recorded daily attendance data, are given in Table 4 for all three schools. Average total waste generation rates ranged from $50.5 \mathrm{~g} \cdot$ student $^{-1} \cdot$ day $^{-1}$ at School C to $137.6 \mathrm{~g} \cdot$ student $^{-1} \cdot$ day $^{-1}$ at School A. The mean generation rates for food waste ranged from $24.7 \mathrm{~g} \cdot$ student $^{-1} \cdot$ day $^{-1}$ at School C to $64.9 \mathrm{~g} \cdot$ student $^{-1} \cdot$ day $^{-1}$ at School A. The overall average for cafeteria waste generation among the three schools was $102.3 \mathrm{~g} \cdot$ student $^{-1} \cdot \mathrm{day}^{-1}$, with food waste alone contributing $52.2 \mathrm{~g} \cdot$ student $^{-1} \cdot$ day $^{-1}$. The percentage contributions of each fraction to the total waste generation rates at the three schools are also shown in Table 4. Food, milk and the paper fractions made up at least $77 \%$ of the cafeteria waste generation at all three schools (Table 4). 
Table 4. Mean generation rates of cafeteria waste fractions from three Florida schools based on waste audits.

\begin{tabular}{|c|c|c|c|c|c|c|c|c|c|c|c|c|}
\hline \multirow{2}{*}{ 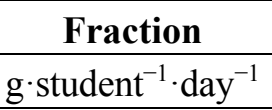 } & \multicolumn{3}{|c|}{ School A $(n=8)^{\text {a }}$} & \multicolumn{3}{|c|}{ School B $(n=7)$} & \multicolumn{3}{|c|}{ School C $(n=5)$} & \multicolumn{3}{|c|}{ Overall $(n=20)$} \\
\hline & Mean & Std. Dev. & $\%$ of Total & Mean & Std. Dev. & $\%$ of Total & Mean & Std. Dev. & $\%$ of Total & Mean & Std. Dev. & $\%$ of Total \\
\hline Food & 64.86 & 14.77 & 47.1 & 57.24 & 8.45 & 57.8 & 24.70 & 2.31 & 48.9 & 52.15 & 19.49 & 51.0 \\
\hline Milk & 30.56 & 9.19 & 22.2 & 2.86 & 2.54 & 2.9 & 0.00 & 0.00 & 0.0 & 13.22 & 15.66 & 12.9 \\
\hline Paper $^{b}$ & 21.06 & 3.34 & 15.3 & 16.22 & 3.56 & 16.4 & 15.47 & 8.36 & 30.6 & 17.97 & 5.44 & 17.6 \\
\hline Plastic $^{c}$ & 20.73 & 5.81 & 15.1 & 17.94 & 3.07 & 18.1 & 9.00 & 1.66 & 17.8 & 16.82 & 6.24 & 16.4 \\
\hline Al \& Glass ${ }^{\mathrm{d}}$ & 0.40 & 0.22 & 0.3 & 4.75 & 2.71 & 4.8 & 1.32 & 0.67 & 2.6 & 2.16 & 2.53 & 2.1 \\
\hline Total & 137.60 & 16.75 & 100.0 & 99.01 & 11.86 & 100.0 & 50.49 & 7.22 & 100.0 & 102.32 & 37.33 & 100.0 \\
\hline
\end{tabular}

a $n=$ days of sampling; ${ }^{\mathrm{b}}$ Paper includes: Cardboard, milk cartons, office paper, pasteboard, paper plates, and tissue paper; ${ }^{\mathrm{c}}$ Plastic includes: Plastic bags, plastic bottles, plastic containers, plastic packaging, plastic wrap, Styrofoam, straws, utensils, and zipper bags; ${ }^{\mathrm{d}} \mathrm{Al} \&$ Glass includes: Aluminum cans, aluminum foil, and glass. 


\section{Discussion}

There is an inherent uncertainty when using a limited data set of waste audits to estimate food waste generation rates at schools. Within the current data, the standard deviations of the mean generation rates are quite high (Table 4). While the mean per student food waste generation rates were somewhat similar between Schools A and B, 64.9 and $57.2 \mathrm{~g} \cdot$ student $^{-1} \cdot$ day $^{-1}$ respectively, the mean per student food waste generation rate at School C, $24.7 \mathrm{~g} \cdot$ student $^{-1} \cdot$ day $^{-1}$, was much lower than those of the other schools. There are a number of potential reasons why School $\mathrm{C}$ had lower food waste generation numbers. Because no food was prepared in the cafeteria at School C, there was no kitchen waste, as was present at School B. Since lunches were selected by students from a daily order menu provided by off-campus restaurants, the food would likely be more palatable to the students than school-provided meals, and therefore there may have been less uneaten food wasted at School C than at School A or B. Also, School $\mathrm{C}$ did not provide breakfast, which reduced the number of meals served in the cafeteria. All public schools in Florida, including School A and School B, are required to offer breakfast, while School C, being a private school, is not subject to this requirement.

Another important factor to consider when comparing food waste generation rates among schools is the percentage of students who receive a school-provided lunch, which can be impacted by a number of factors, including family income and grade level. Smith and Cunningham-Sabo [6] measured plate waste from school lunches in a school district in Northern Colorado and found that at a higher-income elementary school (35\% of students eligible for free or reduced-cost lunch) $63 \%$ of students received a school-provided lunch, while at a lower-income elementary school $(64 \%$ eligible for free or reduced-cost lunch) $77 \%$ of students received a school-provided lunch. The authors found that there was significantly higher food waste of all types from the lower income schools than the higher income schools. In the present study, School A and School B had similar income levels, with 53\% and $59 \%$ eligibility for free or reduced-cost lunch, respectively. However, $65 \%$ of students received a school-provided lunch at School A, while $36 \%$ of students received a school-provided lunch at School B (Table 1). This may have been due to the age differences between the students because elementary school students may be more likely than high school students to receive a school-provided lunch. While the overall food waste generation rates were somewhat similar between Schools A and B, waste from the kitchen contributed significantly to the food waste at School B. On average during the audit, kitchen food waste accounted for approximately $40 \%$ of the food waste collected from School B (data not shown). Therefore, the food waste from the dining area of the cafeteria was in fact much lower at School B than School A. Thus, the present study indicates that a higher level of school-provided meals leads to a higher food waste generation rate. At School C, 37\% of students received a catered lunch, which was similar to the percentage of school-provided lunches at School B, and School C had the lowest food waste from the dining area. Assuming that the students who do not receive a school-provided lunch (35\% and 64\% at Schools A and B, respectively) or a catered lunch (63\% at School C) bring their lunch from home, this study suggests that lunch brought from home results in less food waste from the dining area of the cafeteria compared to served lunches. This may be due to students or their parents packing the types and amounts of food that they will eat. Also, the students may bring whatever is not eaten from these lunches out of the cafeteria to eat later in the day or take home with them. Studies have shown that a large percentage of school-provided meals is discarded [6-8]. Measuring the difference between food 
waste generation rates from school-provided lunches and lunches brought from home is an area of potential future research.

A notable difference between the schools was the amount of milk wasted. School A showed the highest amount of milk waste, as expected, due to the younger elementary school children being routinely served milk over other beverages. High school students may be less likely to take milk with their meals and, since there were vending machines in the cafeteria, they may have elected to drink soda, juice, or water instead. Also, since School B had much fewer students that were served a school-provided meal, there was less opportunity for students to receive milk. Another factor in milk waste was the volume provided to the students. At both School A and School B, milk was provided in half-pint $(0.24 \mathrm{~L})$ cartons. This may have been too much milk for the average elementary student to drink. In fact, unopened cartons of milk were commonly found in the waste at School A. School C did not provide milk and there was no measurable amount of liquids collected in the cafeteria waste.

The mean weight of food waste generated from the school cafeterias in the present study varied from $64.9 \mathrm{~g} \cdot$ student $^{-1} \cdot$ day $^{-1}$ at School A to only $24.7 \mathrm{~g} \cdot$ student $^{-1} \cdot$ day $^{-1}$ at School C, with an overall average for all schools of $52.2 \mathrm{~g} \cdot$ student $^{-1} \cdot \mathrm{day}^{-1}$ (Table 4), which is approximately the weight of half a small apple or one and a half slices of bread. These measurements are significantly lower than school food waste generation values estimated by CDEEP [15] and Griffin et al. [16] that ranged from 159 to $227 \mathrm{~g} \cdot$ student $^{-1} \cdot$ day $^{-1}$ respectively, but are closer to the level estimated by MPCA [22] of $56.4 \mathrm{~g} \cdot$ student $^{-1} \cdot \mathrm{day}^{-1}$. The levels are also lower than food waste generation rates measured by Hollingsworth et al. $[17,18]$ of 130 and $171 \mathrm{~g} \cdot$ student $^{-1} \cdot$ day $^{-1}$, respectively. One reason that food waste generation rates found in the current study are lower could be an increased reliance on pre-packaged and pre-prepared food at these schools, which was empirically observed during the audits and through discussions with the cafeteria staff. For instance, at School A, instead of serving a whole apple, the students received pre-packaged slices of apples which would eliminate the disposal of apple cores into the food service waste stream. Graunke and Wilkie [23] also found a high food waste generation rate of $158.8 \mathrm{~g} \cdot$ student $^{-1} \cdot$ day $^{-1}$ at a university dining hall. However, this dining hall was operated as a buffet and all food was prepared on-site. The kitchen waste from food preparation accounted for $72.6 \mathrm{~g} \cdot$ student $^{-1} \cdot$ day $^{-1}$ in this study, while post-consumer food waste was $86.2 \mathrm{~g} \cdot$ student $^{-1} \cdot$ day $^{-1}$ [23].

Although food waste was the main focus of the present study, the generation rates of other components of the cafeteria waste that were measured in the audits were compared to available literature. Data from the Hollingsworth et al. [17,18] studies, which date from the early 1990s, was used to calculate the contribution of only the paper fraction (cardboard, pasteboard, paper bags, and napkins) of the school cafeteria waste stream, yielding paper fraction generation rates of 34 and $40 \mathrm{~g} \cdot \mathrm{student}^{-1} \cdot \mathrm{day}^{-1}$, respectively. The current study found paper fraction generation rates ranging from $15.5 \mathrm{~g} \cdot \mathrm{student}^{-1} \cdot \mathrm{day}^{-1}$ at School $\mathrm{C}$ to $21.1 \mathrm{~g} \cdot$ student $^{-1} \cdot \mathrm{day}^{-1}$ at School A (Table 4) that are close to half of the estimated generation rates from the Hollingsworth studies. In contrast, the plastic fraction in the current study ranged from 9.0 to $20.7 \mathrm{~g} \cdot$ student $^{-1} \cdot \mathrm{day}^{-1}$ (Table 4), while plastic fraction generation rates in the Hollingsworth et al. [17,18] studies were calculated to range from only 3.4 to $3.8 \mathrm{~g} \cdot \mathrm{student}^{-1} \cdot \mathrm{day}^{-1}$, much lower than in the current study. The difference in paper and plastic generation rates in the present study compared to the Hollingsworth et al. $[17,18]$ studies may be traced to the fact that the use of plastic as a packaging material has increased substantially in recent years. This was empirically observed during the waste audits with a predominance of plastic packaging compared to paper or cardboard packaging 
in evidence. The apparent change in waste generation over time highlights the need for current audits in order to determine accurate component generation rates.

The waste audits revealed that food waste comprised the majority of the cafeteria waste stream. Diverting this food waste from disposal at landfills presents a clear opportunity for increasing the sustainability of school cafeterias. Also, because this food waste is generated at a single point, diverting school cafeteria food waste can be a low-hanging fruit in addressing the problem of food waste. There are two primary approaches to diverting school food waste: reduction and recycling.

Reducing the amount of food waste generated at schools by preventing food from being discarded offers perhaps the most impactful solution to diverting school food waste from landfills. With the rules set by the NSLP standards, school-provided lunches must meet certain criteria and, especially with the Healthy, Hunger-Free Kids Act requiring each student to take a fruit or vegetable, there are some unique challenges to reducing food waste from school-provided lunches. This can be compounded by younger children's tendency to be selective eaters [26]. However, there are a number of strategies that have been researched in order to reduce the amount of food waste from lunches provided under the NSLP. One strategy includes providing adequate time for students to eat and serving lunch at an appropriate time of day. Studies have shown that scheduling recess prior to lunch can significantly increase consumption and reduce food waste $[4,27]$. Other strategies include improving the quality and acceptance of food, launching nutrition education campaigns, using appropriate portion sizes, and allowing self-service fruit and vegetable bars [28]. Involving students in cooking and food preparation through classroom activities could increase their acceptance of different foods and increase consumption of fruits and vegetables [29]. Providing incentives or rewards to students for eating their fruits and vegetables is another effective food waste reduction strategy [12]. Even serving food with an attractive name may reduce the amount of food waste. One study found that calling carrots "X-ray vision carrots" approximately doubled the amount of carrots eaten ( $65.9 \%$ eaten) versus calling the carrots "Food of the day" (32.0\% eaten) or unnamed (35.1\% eaten) [30]. These studies show that, with some research and creativity, there is great potential to reduce the amount of food waste generated from schools by adjusting how food is served and/or employing behavior change strategies.

The second route for diverting school food waste is through collecting and recycling food waste. Waste is typically collected at a single point at the school, such as a dumpster behind the cafeteria, which allows collection of a large quantity of food waste in one location. Also, because school cafeterias are typically a more controlled environment than other food service locations, employing strategies for source separation and collection would be more feasible. Many of the plastic waste items found in the present study could be replaced with durable products that would be washed and reused, such as plates and metal utensils. Not only would this reduce the overall waste from the cafeteria, but a "cleaner" food waste stream would be generated. By reducing the number of disposable items used in the cafeteria, combined with focused training of students and cafeteria staff, and interpretive signage to highlight designated receptacles for food waste, a source-separated food waste stream could be generated from school cafeterias, which would greatly facilitate opportunities for food waste recycling. Also, recycling programs offer valuable educational experiences for students that will continue to provide long-term benefits to society.

Although food waste recycling is lower than food waste reduction on the Food Recovery Hierarchy developed by the United States Environmental Protection Agency [31], food waste recycling has many 
benefits and is useful for diverting unavoidable food waste (e.g., food preparation waste or inedible portions of food) from landfills. Food waste has high moisture content, is readily degradable, and contains significant plant nutrients [32]. The most beneficial means of recycling food waste is either by composting into soil amendments or by conversion via anaerobic digestion into biogas and fertilizer products. In both composting and anaerobic digestion, nutrients contained in the food waste can be recovered and reused. Anaerobic digestion has the added benefit of generating a renewable bioenergy (biogas) that can be used as a replacement for natural gas [33]. Depending on available space at a school or the technology available in the surrounding community, on-campus composting or anaerobic digestion could feasibly be incorporated into the school's facility operations. Composting is already being practiced on a small scale at many schools and, with some investment, composting operations could be expanded to handle cafeteria food waste. These operations could generate a steady supply of compost that could be incorporated synergistically to promote on-campus gardening and food production. This could in turn further help reduce food waste because school gardens have been shown to increase students' consumption of fruits and vegetables [34]. Anaerobic digestion could be implemented on school campuses using small-scale digesters. These could be operated through partnerships with local anaerobic technology providers, or by the school's facility operations themselves. Biogas, with appropriate equipment, could be used for cooking in the cafeteria's kitchen, offsetting fossil fuel use at the cafeteria. The biofertilizer by-product of anaerobic digestion could also be used to support on-campus gardening activities. Alternatively, a centralized anaerobic digester could be constructed to handle food waste from several schools within a school district.

The State of Florida Department of Environmental Protection has set a goal of reducing the level of recyclable municipal solid waste (MSW) sent for landfill disposal by at least $75 \%$ by 2020 to improve environmental sustainability [35]. Therefore, focusing on recycling the non-food waste materials is critical to meeting this goal. Through separating food waste from the other materials, there is a synergistic effect that can improve recycling of the other materials in the cafeteria waste. Most of the materials collected during the audits were heavily soiled with food residues from contact with food waste in the waste bins. This contamination can be particularly problematic for recycling some of these materials. Therefore, establishing or improving the existing source separation of recyclables through education and awareness is essential in order to divert clean recyclables from the waste stream. The types of these materials that are recyclable will depend on the recycling facilities in the area. It should be noted that School C, which had vending machines in the cafeteria, was already collecting recyclables in the cafeteria. School C showed lower generation rates of aluminum cans than School B (1.2\% versus 4.6\% of total cafeteria waste, respectively), which also had vending machines but did not collect recyclables. Paper materials, such as napkins, may be more difficult to separate from food waste for recycling. However, even when contaminated, it is possible to compost or anaerobically digest some or all of the paper fraction in combination with the food waste (including milk). This combination could recycle more than $75 \%$ of the cafeteria waste measured in the present study.

One limitation of this study is the short duration of measurements, with data collection occurring over two weeks or less. The study does not account for seasonal variation within the schools. However, meals at these schools consisted largely of pre-packaged or processed foods with little seasonal fresh produce and, therefore, the seasonal variation of the meals at these particular schools is presumed to be minimal. Regional differences may also exist as different school districts could operate their food services 
differently. Differences in student demographics (age, ethnicity, socio-economic status) also affect student eating habits, which impacts waste generation. To mitigate the effects of these differences, the three schools were purposefully selected to represent students of various backgrounds from a public elementary school, a public technical high school, and a private middle/high school.

\section{Conclusions}

The present study found that food waste comprised the majority of the waste generated from the cafeterias at three different types of schools in Alachua County, Florida. The overall mean waste generation rate on a per student basis was $102.3 \mathrm{~g} \cdot$ student $^{-1}$. day ${ }^{-1}$, with food waste contributing $51.0 \%$ of this waste or $52.2 \mathrm{~g} \cdot$ student $^{-1} \cdot$ day $^{-1}$. Total organic wastes (food, milk and paper) contributed $81.5 \%$ of the overall per student mean waste generation rate. Because of the high amount of organic waste generated, efforts to reduce or recycle organic waste have the potential to greatly reduce the quantity of waste discarded from school cafeterias.

The daily food waste generation rates showed considerable variation between the different schools. This was likely due to the different ages of students and methods of food service. For example, at School $\mathrm{C}$, a private middle and high school where food was catered from off-campus vendors, the food waste generation rates were less than half the food waste generation rates from Schools A and $\mathrm{B}$, which are public schools where food was served in traditional cafeteria style. School B also had a large amount of food waste from the cafeteria's kitchen due to more food preparation in the School B kitchen. School A had the highest mean food waste generation rates of all three schools, even though the kitchen did not generate a measurable amount of food waste. This may be due to a higher number of school-provided meals and a student population of elementary school children who may be more selective eaters or served larger portions than they can eat. The latter may be particularly important in view of the recent Healthy, Hunger-Free Kids Act that requires every child to be served a fruit or vegetable at lunch. Schools B and $\mathrm{C}$ had a higher percentage of students that brought lunch from home compared to School A, which suggests that lunch brought from home results in less food waste from the dining area of the cafeteria. The variable waste generation rates among the different schools highlight the importance of conducting onsite waste audits and understanding where and why food waste is generated in the cafeteria when planning future studies on food waste reduction and recycling at school cafeterias.

\section{Acknowledgments}

This research was funded by the Hinkley Center for Solid and Hazardous Waste Management, Gainesville, Florida. The authors thank the administration and staff at the participating schools for their cooperation. We also acknowledge interns from the BioEnergy and Sustainability School (BESS), a summer research internship program for undergraduates funded by the Florida Agricultural Experiment Station, UF-IFAS for assistance in sorting the school cafeteria waste. 


\section{Author Contributions}

All authors (Ann C. Wilkie, Professor; Ryan E. Graunke, Graduate Student; Camilo Cornejo, Postdoctoral Research Associate) contributed substantially to the research presented in this paper and to the preparation of the final manuscript.

\section{Conflicts of Interest}

The authors declare no conflict of interest.

\section{References}

1. Food and Agriculture Organization of the United Nations (FAO). Food Wastage Footprint: Impacts on Natural Resources, Summary Report; FAO: Rome, Italy, 2013. Available online: http://www.fao.org/docrep/018/i3347e/i3347e.pdf (accessed on 27 October 2014).

2. Food and Agriculture Organization of the United Nations (FAO). Global Food Losses and Food Waste: Extent, Causes, and Prevention; FAO: Rome, Italy, 2011. Available online: http://www.fao.org/docrep/014/mb060e/mb060e.pdf (accessed on 27 October 2014).

3. World Resources Institute (WRI). Food Loss and Waste Protocol: Overview; WRI: Washington, DC, USA, 2014. Available online: http://www.wri.org/sites/default/files/uploads/Food_loss_and_ waste_protocol_Summary_Overview_Oct_2014.pdf (accessed on 27 October 2014).

4. Quested, T.; Ingle, R.; Parry, A. Household Food and Drink Waste in the United Kingdom 2012; Waste \& Resources Action Programme (WRAP): Banbury, UK, 2013. Available online: http://www.wrap.org.uk/content/household-food-and-drink-waste-uk-2012 (accessed on 27 October 2014).

5. Cordingley, F.; Reeve, S.; Stephenson, J. Food Waste in Schools; Waste \& Resources Action Programme (WRAP): Banbury, UK, 2011. Available online: http://www.wrap.org.uk/sites/files/ wrap/Food waste in schools full report .pdf (accessed on 27 October 2014).

6. Smith, S.L.; Cunningham-Sabo, L. Food choice, plate waste and nutrient intake of elementary and middle-school students participating in the US National School Lunch Program. Public Heath Nutr. 2014, 17, 1255-1263.

7. Marlette, M.A.; Templeton, S.B.; Panemangalore, M. Food type, food preparation, and competitive food purchases impact school lunch plate waste by sixth-grade students. J. Am. Diet. Assoc. 2005, 105, 1779-1782.

8. Adams, M.A.; Pelletier, R.L.; Zive, M.M.; Sallis, J.F. Salad bars and fruit and vegetable consumption in elementary schools: A plate waste study. J. Am. Diet. Assoc. 2005, 105, 1789-1792.

9. Food and Nutrition Service, United States Department of Agriculture (FNS/USDA). National School Lunch Program Fact Sheet; FNS/USDA: Washington, DC, USA, 2013. Available online: http://www.fns.usda.gov/sites/default/files/NSLPFactSheet.pdf (accessed on 27 October 2014).

10. Healthy, Hunger-Free Kids Act of 2010. Available online: http://www.gpo.gov/fdsys/pkg/PLAW111publ296/pdf/PLAW-111publ296.pdf (accessed on 27 October 2014). 
11. Watanabe, T. Solutions sought to reduce food waste at schools. Available online: http://www.latimes.com/local/la-me-lausd-waste-20140402-story.html\#page=1 (accessed on 27 October 2014).

12. Just, D.; Price, J. Default options, incentives and food choices: Evidence from elementary-school children. Public Heath Nutr. 2013, 16, 2281-2288.

13. Cohen, J.F.W.; Richardson, S.; Parker, E.; Catalano, P.J.; Rimm, E.B. Impact of the new U.S. Department of Agriculture school meal standards on food selection, consumption, and waste. Am. J. Prev. Med. 2014, 46, 388-394.

14. Byker, C.J.; Farris, A.R.; Marcenelle, M.; Davis, G.C.; Serrano, E.L. Food waste in a school nutrition program after implementation of new lunch program guidelines. J. Nutr. Educ. Behav. 2014, 46, 406-411.

15. Connecticut Department of Energy and Environmental Protection (CDEEP). Updated Mapping of Food Residual Generation in Connecticut; CDEEP: Hartford, CT, USA, 2012. Available online: http://www.ct.gov/deep/lib/deep/compost/compost_pdf/ct_food_residual_generator_report_2012.pdf (accessed on 27 October 2014).

16. Griffin, M.; Sobal, J.; Lyson, T.A. An analysis of a community food waste stream. Agric. Hum. Values 2009, 26, 67-81.

17. Hollingsworth, M.D.; Shanklin, C.; Gench, B.; Hinson, M. Composition of waste generated in six selected school food service operations. Sch. Foodserv. Res. Rev. 1992, 16, 125-130. Available online: http://docs.schoolnutrition.org/newsroom/jcnm/archives/SFSRR 1992 Issue 2.pdf\#page=43 (accessed on 27 October 2014).

18. Hollingsworth, M.D.; Shanklin, C.W.; Cross, E.W. Waste stream analyses in seven selected school food service operations. Sch. Foodserv. Res. Rev. 1995, 19, 81-87. Available online: http://docs.schoolnutrition.org/newsroom/jcnm/archives/SFSRR 1995 Issue 2.pdf\#page=27 (accessed on 27 October 2014).

19. Johnson, H.; Shiralipour, A.; Palmi, S. Food residuals diversion in Florida. Biocycle 1999, 40, 74-78.

20. Florida Department of Education (FDOE). Membership in Florida's Public Schools, 2013-2014; FDOE: Tallahassee, FL, USA, 2013. Available online: http://www.fldoe.org/core/fileparse.php/ 7584/urlt/0069368-pk-12mem1314.xls (accessed on 27 October 2014).

21. Florida Department of Education (FDOE). Staff in Florida's Public Schools, 2013-2014; FDOE: Tallahassee, FL, USA, 2013. Available online: http://www.fldoe.org/core/fileparse.php/7584/ urlt/0069353-staff1314-fulltime.xls (accessed on 28 October 2014).

22. Minnesota Pollution Control Agency (MPCA). Digging Deep through School Trash: A Waste Composition Analysis of Trash, Recycling and Organic Material Discarded at Public Schools in Minnesota; MPCA: St Paul, MN, USA, 2010. Available online: http://www.pca.state.mn.us/ index.php/view-document.html?gid=14235 (accessed on 28 October 2014).

23. Graunke, R.E.; Wilkie, A.C. Converting food waste to biogas: Sustainable gator dining. Sustain. J. Rec. 2008, 1, 391-394.

24. Istead, L.; Shapiro, B. Recognizing the child as knowledgeable other: Intergenerational learning research to consider child-to-adult influence on parent and family eco-knowledge. J. Res. Child. Educ. 2014, 28, 115-127. 
25. Dahlen, L.; Lagerkvist, A. Methods for household waste composition studies. Waste Manag. 2008, $28,1100-1112$.

26. Dovey, T.M.; Staples, P.A.; Gibson, E.L.; Halford, J.C.G. Food neophobia and "picky/fussy" eating in children: A review. Appetite 2008, 50, 181-193.

27. Getlinger, M.J.; Laughlin, C.V.T.; Bell, E.; Akre, C.; Arjmandi, B.H. Food waste is reduced when elementary-school children have recess before lunch. J. Am. Diet. Assoc. 1996, 96, 906-908.

28. Buzby, J.C.; Guthrie, J.F. Plate Waste in School Nutrition Programs: Final Report to Congress; E-FAN-02-009; Economic Research Service/United States Department of Agriculture: Washington, DC, USA, 2002. Available online: http://www.ers.usda.gov/media/887982/efan02009.pdf (accessed on 28 October 2014).

29. Liquori, T.; Koch, P.D.; Contento, I.R.; Castle, J. The Cookshop Program: Outcome evaluation of a nutrition education program linking lunchroom food experiences with classroom cooking experiences. J. Nutr. Educ. 1998, 30, 302-313.

30. Wansink, B.; Just, D.R.; Payne, C.R.; Klinger, M.Z. Attractive names sustain increased vegetable intake in schools. Prev. Med. 2012, 55, 330-332.

31. United States Environmental Protection Agency (US EPA). The Food Recovery Hierarchy. Available online: http://www.epa.gov/foodrecovery/ (accessed on 28 October 2014).

32. Graunke, R.E.; Wilkie, A.C. Examining the mechanisms of short-term solubilization of ground food waste for high-rate anaerobic digestion. Int. Biodeterior. Biodegrad. 2014, 86, 327-333.

33. Wilkie, A.C. Biomethane from biomass, biowaste, and biofuels. In Bioenergy; Wall, J.D., Harwood, C.S., Demain, A., Eds.; American Society for Microbiology: Washington, DC, USA, 2008; pp. 195-205. Available online: http://biogas.ifas.ufl.edu/publs/bioenergy_ch16_asm_ press_2008.pdf (accessed on 28 October 2014).

34. Robinson-O'Brien, R.; Story, M.; Heim, S. Impact of garden-based youth nutrition intervention programs: A review. J. Am. Diet. Assoc. 2009, 109, 273-280.

35. Florida Department of Environmental Protection (FDEP). 75\% Recycling Goal Report to the Legislature; FDEP: Tallahassee, FL, USA, 2010. Available online: http://www.dep.state.fl.us/ waste/quick_topics/publications/shw/recycling/75percent/75_recycling_report.pdf (accessed on 28 October 2014).

(C) 2015 by the authors; licensee MDPI, Basel, Switzerland. This article is an open access article distributed under the terms and conditions of the Creative Commons Attribution license (http://creativecommons.org/licenses/by/4.0/). 